\title{
DEVELOPMENT OF RADIOLOGICAL PROFILES FOR U.S. DEPARTMENT OF ENERGY LOW-LEVEL MIXED WASTES*
}

\author{
B.D. Wilkins, N.K. Meshkov, D.A. Dolak, and Y.Y. Wang \\ Argonne National Laboratory \\ Argonne, Mllinois
}

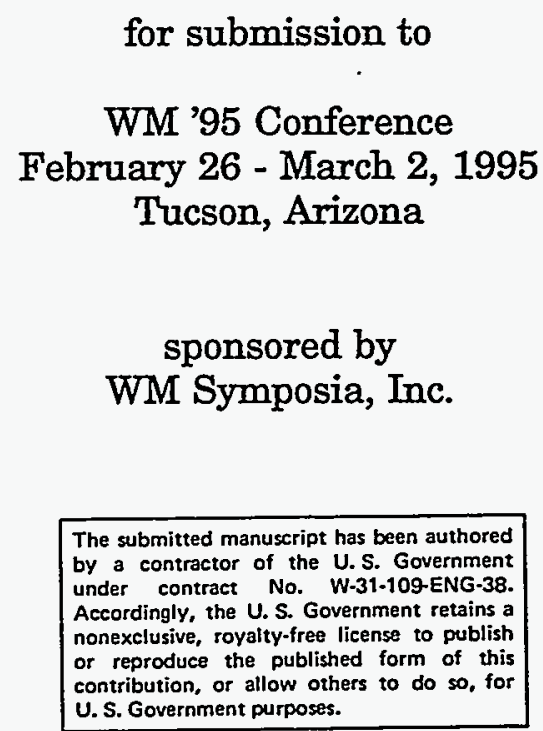

\section{DISCLAIMER}

This report was prepared as an account of work sponsored by an agency of the United States Government. Neither the United States Government nor any agency thereof, nor any of their employees, makes any warranty, express or implied, or assumes any legal liability or responsibility for the accuracy, completeness, or usefulness of any information, apparatus, product, or process disclosed, or represents that its use would not infringe privately owned rights. Reference herein to any specific commercial product, process, or service by trade name, trademark, manufacturer, or otherwise does not necessarily constitute or imply its endorsement, recommendation, or favoring by the United States Government or any agency thereof. The views and opinions of authors expressed herein do not necessarily state or reflect those of the United States Government or any agency thereof.

\section{MASTER}

* Work supported by the U.S. Department of Energy, Assistant Secretary for Environmental Management, under contract W-31-109-Eng-38. 


\section{DISCLAIMER}

Portions of this document may be illegible in electronic image products. Images are produced from the best available original document. 
DEVELOPMENT OF RADIOLOGICAL PROFILES FOR U.S. DEPARTMENT OF ENERGY LOW-LEVEL MIXED WASTES*

B.D. Wilkins, N.K. Meshkov, D.A. Dolak, and Y.Y. Wang

Argonne National Laboratory

Argonne, Illinois

\section{ABSTRACT}

Radiological profiles have been developed by Argonne National Laboratory for low-level mixed wastes (LLMWs) that are under the management of the U.S. Department of Energy (DOE). These profiles have been used in the Office of Environmental Management Programmatic Environmental Impact Statement (EM PEIS) to support the analysis of environmental and health risks associated with the various waste management strategies. The radiological characterization of DOE LLMWs is generally inadequate and has made it difficult to develop a site- and waste-stream-dependent radiological profile for LLMWs. On the basis of the operational history of the DOE sites, a simple model was developed to generate sitedependent and waste-stream-independent radiological profiles for LLMWs. This paper briefly discusses the assumptions used in this model and the uncertainties in the results.

\section{INTRODUCTION}

The U.S. Department of Energy (DOE) Office of Environmental Management (EM) has undertaken a Programmatic Environmental Impact Statement (PEIS). This EM PEIS addresses the environmental and health risks associated with the management of DOE radioactive and hazardous wastes. The treatment, storage, and disposal (TSD) of radioactive low-level mixed wastes (LLMWs) represent a major effort in the EM PEIS. LLMWs are wastes that are both hazardous under the Resource Conservation and Recovery Act (RCRA) (Title 40, Part 261 of the Code of Federal Regulations [CFR]) and meet the definition of low-level waste (LLW) under DOE Order 5820.2A (1).

The major sources of LLMW under DOE management considered in the EM PEIS are (1) currently stored LLMWs awaiting treatment and projected generated wastes from future operations, that is, Waste Management (WM) LLMWs, and (2) Environmental Restoration (ER) wastes, which are obtained from site restoration and decontamination and decommissioning (D\&D) of DOE facilities, and sent to WM for TSD. Approximately $430,000 \mathrm{~m}^{3}$ of WM LLMW are expected (inventory and future generation) through 2014. More than 2,000 waste streams of LLMW at 44 separate DOE sites are identified in the 1994 Mixed Waste Inventory Report (MWIR-2) (2). In the ER "semirestricted" alternative, it is projected that the volume of ER-derived LLMW needing treatment will be approximately 7.3 million $\mathrm{m}^{3}$ through 2030 . The specific ER secondary waste streams that will be sent to

* Work supported by the U.S. Department of Energy, Assistant Secretary for Environmental Management, under contract W-31-109-Eng-38. 
WM have been described in the Automated Remedial Assessment Methodology (ARAM) database provided by Pacific Northwest Laboratory (PNL) $(3,4)$.

To support the EM PEIS effort to determine environmental and health risks associated with the TSD of DOE LLMW, Argonne National Laboratory has established a methodology for estimating radiological and chemical profiles for the more than 2,000 waste streams at $44 \mathrm{DOE}$ sites. Radiological characterization of these waste streams given in the various DOE databases on LLMW is clearly inadequate for the stated task. The databases can, however, be useful in verifying and providing data to establish some simplifying assumptions.

LLMWs are classified into four separate radiological categories. The largest volume ( $>99 \%)$ is contact-handled $(\mathrm{CH})$ waste, which has a surface activity of less than $200 \mathrm{mrem} / \mathrm{h}$. Remote-handled (RH) waste has a surface dose greater than $200 \mathrm{mrem} / \mathrm{h}$. CH wastes are treated separately from RH LLMW. The type of radiation emitied also determines LLMW classification and can affect environmental and health risks. The majority of LLMW (approximately 75\%) is non-alpha waste (less than $10 \mathrm{nCi} / \mathrm{g}$ transuranic [TRU] radionuclide alpha activity). The remaining $25 \%$ of LLMW is alpha LLMW (between 10-100 nCi/g TRU alpha activity). Because of regulatory concerns, the handling and routing for treatment of all LIMWW are performed separately for alpha and non-alpha wastes.

The following sections of this paper cover the procedures and assumptions used to estimate the radiological profiles for LLMW for each site and include a discussion of the uncertainties associated with these results. The estimated chemical profiles associated with LLMW are presented in another paper for this conference (5).

\section{RADIOLOGICAL PROFILES FOR LLMW}

Determination of radionuclide concentrations for LLMW is difficult because there is insufficient information in MWIR-2 or in the current Waste Management Information System (WMIS) databases to quantify the concentration of the various radionuclides. Given the current data, it is not possible to construct precise radiological profiles for each of the LLMW streams at all sites.

The operational mission(s) is primarily responsible for the radionuclides generated at each site. The presence or absence of RCRA contaminants in a waste stream distinguishes LLMW from LLW and is not very likely to affect the relative proportion of radionuclides in the waste. Given that the same mix of radionuclides tends to contaminate both LLW and LLMW at a site, it is assumed that radiological profiles for LLMW are site-dependent but waste-stream-independent. The LLMW radiological profiles developed in the EM PEIS are derived from information on the radiological content of LLW contained within the 1991 Integrated Data Base (IDB) (6).

The IDB has information, accumulated over many years, on the operational history of the larger DOE sites. This information on each site is subdivided into waste volumes, activity concentration $\left(\mathrm{Ci} / \mathrm{m}^{3}\right)$, and source of activity. Because the data have been accumulated over a number of years, they represent the cumulative result of the various DOE waste-generating 
activities over those years. Five major DOE programs generate distinct sources of radioactivity. These sources are (1) fission products, (2) induced activity, (3) uranium/thorium, (4) TRU alpha, and (5) tritium. The IDB data provide radiological profiles near the time of generation for each of these five operations that produced LLW (see Table I).

\section{PLACE TABLE I HERE}

In estimating the radiological profiles for the LLMW in the EM PEIS, it has been assumed that at the time of waste generation, LLMW radiological profiles for each site are the same as those for LLW because the same operational mission(s) is responsible for generating both LLW and LLMW. Furthermore, it has been assumed that radiological profiles are the same for all waste streams at a given site. Treatment facilities for LLMW are not generally expected to be available for treatment until 2003, whereas many LLW treatment facilities are already in operation. Thus, the time interval between generation and treatment will be much greater for LLMW than for LLW. Therefore, it is much more important to account for radioactive decay for LLMW than for LLW. LLW is normally disposed of soon after generation; thus, its radiological profile at the time of disposal will not be much different from that at the time of generation. On the other. hand, because the proposed treatment of LLMW is to begin in 2003, the age of the LLMW at the time of treatment will be much greater than that of LLW. Therefore, the radioactive profile of LLMW at the time of treatment will differ considerably from its profile at the time of generation.

To estimate the time interval between LLMW generation and treatment, the treatment date for all LLMW has been assumed to be 2008 (the midpoint of the proposed treatment period of 2003 through 2013). The average generation date estimates are different for different sites and for the three different waste groups, that is, current inventory, waste projected to be generated over an ensuing 20-year period, and ER waste. The generation dates were arrived at by estimating the average date (given site history) of radionuclide generation, except for the uranium/thorium source term. For the uranium/thorium source term, the generation time is defined as the time of the most recent chemical or isotopic concentration/isolation of the material.

Thus, the principal assumptions on which LLMW radiological profiles were estimated are as follows:

- At the time of waste generation, LLMW radiological profiles for each site are the same as those for LLW at the same site.

- At the time of waste generation at a given site, activity concentrations $\left(\mathrm{Ci} / \mathrm{m}^{3}\right)$ are the same as those for LLW.

- At the time of treatment, the radiological characteristics of LLMW will be different from those of LLW only because of the greater age of the waste. 
- The treatment date for all LLMW is 2008.

- Radiological profiles are assumed to be independent of the waste stream category at a particular site.

- The average generation date of LLMW depends on the site and on whether it comes from inventory, projected generation, or ER.

- The information on LLW does not distinguish between alphacontaminated (TRU content $=10 \mathrm{nCi} / \mathrm{g}-100 \mathrm{nCi} / \mathrm{g}$ ) waste and non-alphacontaminated (TRU $<10 \mathrm{nCi} / \mathrm{g}$ ) waste. This analysis assumes a geometric mean of $33 \mathrm{nCi} / \mathrm{g}$ (TRU) for the alpha-contaminated LLMW and 33/20, approximately $1.7 \mathrm{nCi} / \mathrm{g}$ (TRU), for the non-alphacontaminated LLMW. These values are equivalent to $0082(\mathrm{Ci}) / \mathrm{m}^{3}$ and $.004 \mathrm{Ci} / \mathrm{m}^{3}$, respectively, in TRU activity (estimated density $=2,500 \mathrm{~kg} / \mathrm{m}^{3}$ for the two types of waste).

- For sites with gaseous diffusion plants (GDPs) or that store GDP waste, adjustments were made to the uranium/thorium source term by the addition of technetium-99 (Tc-99), which through carryover of gaseous technetium (Tc-99) fluoride in the GDP process, is present (in small amounts) in this specific waste type.

The proportional LLMW source term distribution by site and the site-dependent activity percentages for the CH LLMW (non-alpha) and CH LLMW (TRU alpha) are given in Tables II and III. These tables were derived from IDB data on the accumulated radioactivity (in curies) for LLW at each site. The tables list the activity percentages near the time of generation of the radionuclides. For major sites, the assumed average times of radionuclide generation/isolation are given in Table IV. The coupling of the appropriate waste ages, activity percentages, and source term radiological profiles will generate site-dependent radiological profiles and activity concentrations for LLMW. The individual site radiological profiles are reported in a technical support document (9). Table $V$ lists the estimated radiological profiles for WM LLMW at the average time of treatment (2008) for a number of larger DOE sites. The methodology presented here predicts substantially different radiological profiles expected at the time of treatment for the different sites. Such a result is consistent with the widely varying programmatic missions of the different DOE sites.

\section{PLACE TABLES II, III, IV, AND V HERE}

This procedure can be carried beyond the time of treatment of the waste to times of interest for disposed waste. Figure I illustrates the behavior of radioactive hazard with time for a typical DOE waste stream containing plutonium. This activity time plot was obtained by ordering radionuclides according to increasing half-life and plotting cumulative sums of their activity concentrations against time. The activity concentrations were multiplied by a weighing factor that represents the radiological risk to human health (10). This figure illustrates as a function of time the ingrowth of americium-241 (Am-241) and later of 
neptunium-237 (Np-237). An example might be Rocky Flats Environmental Technology Site (RFETS). Here the projected radiological profile is dominated by plutonium-241 (Pu-241) near the time of treatment. Over a time scale of hundreds of years, the Pu-241 decays away, but the resultant Am-241 grows in to become the dominant radionuclide. In a time scale of thousands of years, the Am-241 decays and Np-237 becomes prominent. Such information is useful in determining the environmental and health risks associated with disposed waste from RFETS.

\section{PLACE FIGURE I HERE}

The DOE sites included within Tables II and III contain more than $98 \%$ of the total LLMW. Each of the additional small DOE sites were approximated as being similar in radiological profile to one of the large DOE sites included within Tables II and III. Table VI shows the assumed similarities between the radiological profiles of the small and large DOE sites used in this analysis.

\section{PLACE TABLE VI HERE}

The determination of radiological profiles for ER LLMW was hampered by incomplete radiological characterization of the waste in the ARAM data. Examination of ER-derived LLMW radionuclide concentrations indicated a similarity to the site-based radiological profiles used for the WM LLMW. For this study, the site-dependent ER LLMW radionuclide source terms were assumed to be identical to those used for WMI LLMW with the following three differences. First, the mean time for generation of radionuclides in all ER wastes was assumed to be 1965. This produces a different adjustment to aging for the ER wastes compared with non-current-inventory WM LLMW at each site (see Table IV). Second, the longer time for radioactive decay and dilution of ER wastes by nonradioactive external materials, such as soil, old packaging, and groundwater, tends to lower the average concentration per unit volume of ER LLMW compared with similar WM LLMW. The ARAM database indicates that the average expected activity concentration $\left(\mathrm{Ci} / \mathrm{m}^{3}\right)$ for $\mathrm{ER}$ wastes is about $10 \%$ of the WM LLMW activity concentration estimate derived from IDB LLW information. Thus, the radionuclide concentration of ER LLMW is taken as one-tenth the activity concentration for equivalent WM LLMW at a given site. Finally, the ARAM database lists the ER waste at Sandia National Laboratories (New Mexico) (SNL-NM) as being contaminated with uranium. Thus, in Table V, the radiological composition of SNL-NM ER LLMW is similar to that of the Fernald Environmental Management Project (FEMP) and not that of the Savannah River Site (SRS) as shown for WM waste.

\section{UNCERTAINTIES IN RADIOLOGICAL PROFILES}

The major source of uncertainty in the radiological profiles is the lack of adequate quantitative radiological characterization of LLMW streams compiled in the MWIR-2 database. For the majority of the waste streams, radiological content is described only qualitatively. For example, a waste stream will be described as containing TRU radionuclides but identities and concentrations are not given. In other cases, the radionuclide 
quantities are given but are not appropriately aged and the waste generation date is unknown.

Because reliable data providing contaminant characterization of waste streams are not available, models were constructed for radiological profiles. The uncertainties in radiological profiles arise from the assumptions made in developing the profiles. Two assumptions in particular contribute to the uncertainties for radiological profiles: (1) radiological profiles depend only on the site and not on the particular waste stream and (2) total activity concentrations in LLMW streams at the time of generation are the same as those in the LLW streams.

The first assumption, namely that radiological profiles do not depend on the waste treatment category, is likely to introduce the largest errors. Because different radionuclides have different solubilities, their proportions in aqueous and organic liquids will be different than in solids and sludges. For example, the proportion of tritium (H-3) may be underestimated in liquid wastes and overestimated in solid wastes, thereby affecting $\mathrm{H}-3$ estimates in air and water emissions. Variations in radiological profiles among the various solid waste streams are less important because such variations will have a much less significant impact on emissions source terms.

The second assumption is that at the time of waste generation, total activity concentrations in LLMW streams are the same as in LLW streams. It is reasonable to assume that LLMW streams are similar in radionuclide composition to LLW streams because the radionuclides present in both streams are generated by the same processes. However, the total initial activity concentration in LLMW is not necessarily the same as that in LLW. The uncertainty in the total initial activity concentrations will introduce uncertainties in total radioactivity content in emission source terms. However, the impact of this uncertainty on comparisons among the different WM alternatives will be less significant because the errors in total activity concentration estimates will tend to be in the same direction for all alternatives.

Other assumptions pertain to the age of the LLMW, values assumed for the TRU content, and Tc-99 content of wastes from GDPs. Uncertainties introduced by these assumptions are expected to be of lesser importance than those arising from the two assumptions discussed above.

\section{REFERENCES}

1. U.S. DEPARTMENT OF ENERGY, "Radioactive Waste Management" DOE Order 5820.2A, Washington, D.C. (1985)

2. U.S. DEPARTMENT OF ENERGY, "Mixed Waste Inventory Report: Final Phase II Mixed Waste Inventory Report Data," EM-352, Washington, D.C. (1994). 
3. PACIFIC NORTHWEST LABORATORY, "Secondary Waste Stream Data on the D\&D of DOE Facilities," Letter from D. King to B. Wilkins, Argonne National Laboratory, (April 1994).

4. PACIFIC NORTHWEST LABORATORY, "Methodology for Selecting Technologies and Estimating Waste Volumes, Costs, and Labor Requirements for Environmental Restoration," Draft, Richland, Wash. (1994).

5. Y.Y. WANG et al., "Development of Chemical Profiles for U.S. Department of Energy Low-Level Mixed Wastes," presented at WM '95 conference, February 26 - March 2, 1995, Tucson, Ariz. (1995).

6. U.S DEPARTMENT OF ENERGY, "Integrated Data Base for 1992: U.S Spent Fuel and Radioactive Waste Inventories, Projections, and Characteristics, " DOE/RW0006, Rev. 8, prepared by Oak Ridge National Laboratory, Oak Ridge, Tenn., for U.S. Department of Energy, Washington, D.C. (1992).

7. U.S DEPARTMENT OF ENERGY, "Disposal of Solid Low.Level and Mixed Low-Level Waste during 1990," DOE/EH-0332P, prepared by G. Roles, Air, Water, and Radiation Division, Office of Environmental Guidance, Washington, D.C. (1995).

8. J.R. COOK, et al., "Environmental Information Document, New Low-Level Radioactive Waste Storage/Disposal Facilities at the Savannah River Plant, DPST-85-862, prepared by E.I. du Pont de Nemours and Company Inc., Savannah River Laboratory, Aiken, S.C. (1987).

9. B.D. WILKINS et al., Argonne National Laboratory, unpublished information (Nov. 1994).

10. T.L. GILBERT and N.K. MESHKOV, "Selecting a Land Disposal Alternative," in NearSurface Disposal," J.H. Kittle (editor), Harwood Academic Publishers, New York, N.Y. (1989). 
TABLE I. LWW Representative Source Term Distributions

\begin{tabular}{|c|c|c|c|c|c|}
\hline Nuclide & $\begin{array}{c}\% \\
\text { Activity }\end{array}$ & Nuclide & $\begin{array}{c}\% \\
\text { Activity }\end{array}$ & Nuclide & $\begin{array}{c}\% \\
\text { Activity }\end{array}$ \\
\hline $\begin{array}{l}\text { Uranium/Throrium } \\
\text { Thallium (Th)-208 } \\
\text { Lead (Pb)-212 } \\
\text { Bismuth (Bi)-212 } \\
\text { Polonium (Po)-212 } \\
\text { Po-216 } \\
\text { Radium (Ra)-224 } \\
\text { Ra-228 } \\
\text { Actinum (Ac)-228 } \\
\text { Thorium (Th)-231 } \\
\text { Th-231 } \\
\text { Th-232 } \\
\text { Th-234 } \\
\text { Protactinium (Pa)- } \\
\text { 234m } \\
\text { Pa-234 } \\
\text { Uranium (U)-235 } \\
\text { U-238 } \\
\quad \text { Total } \\
\quad \text { Fission Product } \\
\\
\text { H-3 } \\
\text { Co-60 } \\
\text { Ni-63 } \\
\text { Strontium (Sr)-90 } \\
\text { Yttrium (Y)-90 } \\
\text { Technetium (Tc)-99 } \\
\text { Ruthenium (Ru)-106 } \\
\text { Rhodium (Rh)-106 } \\
\text { Antinomy (Sb)-125 } \\
\text { Tellurium (Te)-125m } \\
\text { Cs-134 } \\
\text { Cs-137 } \\
\text { Ba-137m } \\
\text { Cerium (Ce)-144 }\end{array}$ & $\begin{array}{l}0.0017 \\
0.0045 \\
0.0045 \\
0.0029 \\
0.0029 \\
0.0045 \\
0.0269 \\
0.0269 \\
0.0045 \\
0.0259 \\
0.273 \\
33.197 \\
33.197 \\
\\
0.0034 \\
0.0258 \\
33.197 \\
100\end{array}$ & \begin{tabular}{l}
$\quad$ Fission \\
\multicolumn{1}{c}{ Product-Cont. } \\
Praseodymium (Pr)-144 \\
Pr-144m \\
Promethium (Pm)-147 \\
Samarium (Sm)-151 \\
Europium (Eu)-152 \\
Eu-154 \\
Eu-155 \\
Pu-238 \\
Pu-239 \\
Pu-240 \\
Pu-241 \\
Am-241 \\
Total
\end{tabular} & $\begin{array}{l}5.490 \\
0.066 \\
13.40 \\
0.131 \\
0.002 \\
0.343 \\
0.272 \\
0.413 \\
0.004 \\
0.002 \\
0.462 \\
0.006 \\
100\end{array}$ & $\begin{array}{l}\text { TRU (<100nCi/g) } \\
\text { Plutonium (Pu)-238 } \\
\text { Pu-239 } \\
\text { Pu-240 } \\
\text { Pu-241 } \\
\text { Americium (Am)-241 } \\
\text { Curium (Cm)-242 } \\
\text { Cm-244 Total } \\
\quad \text { Tritium } \\
\text { H-3 }\end{array}$ & $\begin{array}{l}2.62 \\
0.2 \\
0.7 \\
96.4 \\
0.004 \\
0.056 \\
0.02 \\
100 \\
100\end{array}$ \\
\hline
\end{tabular}

a Based on the representative uranium/thorium nuclide distribution in the $I D B(6)$.

b Based on the distribution of activation products in LLW disposed of in 1990 (7).

c Based on the distribution in the $\mathrm{TB}(6)$.

d Based on the isotopic distribution for fission product waste at SRS, decayed for five years (8). Total adds to slightly more than $100 \%$ due to rounding. 
TABLE II. Activity Concentrations and Percentages by Activity Near the Time of Generation of CH LLMW (non-alpha)

\begin{tabular}{|l|c|c|c|c|c|c|}
\hline \multicolumn{1}{|c|}{ Site $^{\mathrm{a}}$} & $\begin{array}{c}\text { Fission } \\
\text { Products }\end{array}$ & U/Th & H-3 & TRU & $\begin{array}{c}\text { Induced } \\
\text { Activity }\end{array}$ & $\begin{array}{c}\text { Activity } \\
\text { Concentration } \\
\left(\mathrm{Ci} / \mathrm{m}^{3}\right)\end{array}$ \\
\hline FEMP & $-\mathrm{b}$ & $100 \%$ & - & - & - & .008 \\
Hanford & $90 \%$ & $.01 \%$ & $5 \%$ & $.025 \%$ & $5 \%$ & 16.5 \\
INEL & $6 \%$ & $0.1 \%$ & $6 \%$ & $.005 \%$ & $88 \%$ & 80 \\
LANL & $2 \%$ & $.01 \%$ & $95 \%$ & $.08 \%$ & $3 \%$ & 5.1 \\
LLNL & $0.1 \%$ & $.01 \%$ & $99 \%$ & $.005 \%$ & - & 105 \\
ORNL & $30 \%$ & $1 \%$ & $1 \%$ & $.3 \%$ & $68 \%$ & 2.9 \\
PGDP & - & $100 \%$ & - & - & - & 2.7 \\
PORTS & - & $100 \%$ & - & - & - & .002 \\
RFETS & - & $0.1 \%$ & - & $99.9 \%$ & - & .005 \\
SRS & $7 \%$ & $.01 \%$ & $46 \%$ & $.025 \%$ & $47 \%$ & 16.5 \\
\hline
\end{tabular}

a Abbreviations: FEMP = Fernald Environmental Management Project, H-3 = tritium, INEL = Idaho National Engineering Laboratory, LANL = Los Alamos National Laboratory, LLNL = Lawrence Livermore National Laboratory, ORNL = Oak Ridge National Laboratory, PGDP = Paducah Gaseous Diffusion Plant, PORTS $=$ Portsmouth Gaseous Diffusion Plant, RFETS = Rocky Flats Environmental Technology Site, SRS = Savannah River Site, $\mathrm{Th}=$ thorium, and $\mathrm{U}=$ uranium .

b A hyphen indicates no significant concentration.

TABLE $\mathrm{III}$ Activity Concentrations and Percentages by Activity Near the Time of Generation of CH LLMW (alpha)

\begin{tabular}{|l|c|c|r|r|c|c|}
\hline \multicolumn{1}{|c|}{ Site } & $\begin{array}{c}\text { Fission } \\
\text { Products }\end{array}$ & U/Th & $\mathrm{H}-3$ & TRU & $\begin{array}{c}\text { Induced } \\
\text { Activity }\end{array}$ & $\begin{array}{c}\text { Activity } \\
\text { Concentration } \\
\left(\mathrm{Ci} / \mathrm{m}^{3}\right)\end{array}$ \\
\hline Hanford & $90 \%$ & $.01 \%$ & $5 \%$ & $.5 \%$ & $5 \%$ & 16.6 \\
INEL & $6 \%$ & $0.1 \%$ & $6 \%$ & $0.1 \%$ & $88 \%$ & 80.1 \\
LANL & $2 \%$ & $.01 \%$ & $93 \%$ & $1.6 \%$ & $3 \%$ & 5.2 \\
LLNL & $0.1 \%$ & $.01 \%$ & $99 \%$ & $0.1 \%$ & $-\mathbf{a}^{2}$ & 105 \\
ORNL & $28 \%$ & $1 \%$ & $1 \%$ & $6 \%$ & $64 \%$ & 3.0 \\
RFETS & - & $0.1 \%$ & - & $99.9 \%$ & - & 0.1 \\
SRS & $7 \%$ & $.01 \%$ & $46 \%$ & $.5 \%$ & $47 \%$ & 16.6 \\
\hline
\end{tabular}

a A hyphen indicates no significant concentration. 
TABLE IV. Time of Radionuclide Generation $^{\mathrm{a}}$

\begin{tabular}{|c|c|c|c|}
\hline Site & $\begin{array}{l}\text { Current } \\
\text { Inventory }\end{array}$ & $\begin{array}{c}20-y r \\
\text { Projected } \\
\text { Generation }\end{array}$ & $\begin{array}{c}\text { ER } \\
\text { Waste }\end{array}$ \\
\hline FEMP & 1965 & 1965 & 1965 \\
\hline Hanford & 1965 & 1965 & 1965 \\
\hline INEL & 1965 & 2000 & 1965 \\
\hline LANL & 1985 & 2000 & 1965 \\
\hline LLNL & 1985 & 2000 & 1965 \\
\hline ORR & 1965 & 1985 & 1965 \\
\hline PGDP & 1965 & 1985 & 1965 \\
\hline PORTS & 1965 & 1985 & 1965 \\
\hline RFETS & 1965 & 1985 & 1965 \\
\hline SRS & 1965 & 1985 & 1965 \\
\hline NTS $^{b}$ & $N A^{c}$ & NA & 1965 \\
\hline
\end{tabular}

a $1965=43 \mathrm{yr}$ to treatment, $1985=23 \mathrm{yr}$ to treatment, and $2000=8 \mathrm{yr}$ to treatment (treatment assumed as 2008).

b NTS = Nevada Test Site.

c $\mathrm{NA}=$ not applicable because no WM waste is listed in MWIR-2 (2). 
TABLE V. Estimated Radiological Profiles for LLMW near the Time of Treatment for Some of the Larger DOE Sites (Non-Alpha Wastes)

\begin{tabular}{|c|c|c|c|c|c|c|c|c|c|}
\hline \multicolumn{2}{|c|}{ FEMP } & \multicolumn{2}{|c|}{ HANFORD } & \multicolumn{2}{|c|}{ INEL } & \multicolumn{2}{|c|}{ LANL } & \multicolumn{2}{|c|}{ RFETS } \\
\hline Nuclide & $\begin{array}{c}\text { Activity } \\
\text { Concentration } \\
\mathrm{Ci} / \mathrm{m}^{3}\end{array}$ & Nuclide & $\begin{array}{c}\text { Activity } \\
\text { Concentration } \\
\mathrm{Ci} / \mathrm{m}^{3}\end{array}$ & Nuclide & $\begin{array}{c}\text { Activity } \\
\text { Concentration } \\
\mathrm{Ci} / \mathrm{m}^{3}\end{array}$ & Nuclide & $\begin{array}{c}\text { Activity } \\
\text { Concentration } \\
\mathrm{Ci} / \mathrm{m}^{3}\end{array}$ & Nuclide & $\begin{array}{c}\text { Activity } \\
\text { Concentration } \\
\mathrm{Ci} / \mathrm{m}^{3}\end{array}$ \\
\hline $\begin{array}{l}\text { U-238 } \\
\text { Pa-234 } \\
\text { Th-234 } \\
\text { Tc-99 } \\
\text { Th-232 } \\
\text { Ra-228 } \\
\text { Ac-228 } \\
\text { Th-231 } \\
\text { U-235 } \\
\text { Pb-212 } \\
\text { Bi-212 } \\
\text { Po-216 } \\
\text { Ra-224 } \\
\text { Th-228 } \\
\text { Pa-234 } \\
\text { Po-212 }\end{array}$ & $\begin{array}{l}2.64 \times 10^{-3} \\
2.64 \times 10^{-3} \\
2.64 \times 10^{-3} \\
3.98 \times 10^{-5} \\
2.17 \times 10^{-5} \\
2.14 \times 10^{-} 6 \\
2.14 \times 10^{-} 6 \\
2.06 \times 10^{-} 6 \\
2.06 \times 10^{-} 6 \\
3.60 \times 10^{-} 7 \\
3.60 \times 10^{-7} 7 \\
3.60 \times 10^{-} 7 \\
3.60 \times 10^{-7} 7 \\
3.60 \times 10^{-} 7 \\
2.72 \times 10^{-7} 7 \\
2.32 \times 10^{-7} 7\end{array}$ & $\begin{array}{l}\text { Cs-137 } \\
\text { Ba-137m } \\
\text { Sr-90 } \\
\text { Y-90 } \\
\text { Nc-63 } \\
\mathrm{H}-3 \\
\mathrm{Pu}-238 \\
\mathrm{Sm}-151 \\
\mathrm{Pu}-241 \\
\text { Ni-59 } \\
\text { Eu-154 } \\
\mathrm{Co}-60 \\
\text { Am-241 } \\
\mathrm{Pu}-239 \\
\mathrm{U}-238 \\
\mathrm{~Pa}-234 \mathrm{~m} \\
\mathrm{Th}-234 \\
\mathrm{Tc}-99 \\
\mathrm{Pu}-240 \\
\mathrm{Nb}-94\end{array}$ & $\begin{array}{l}9.79 \times 10^{-1} \\
9.15 \times 10^{-1} \\
8.72 \times 10^{-1} \\
8.72 \times 10^{-1} \\
1.94 \times 10^{-1} \\
7.32 \times 10^{-2} \\
4.38 \times 10^{-2} \\
1.41 \times 10^{-2} \\
9.71 \times 10^{-3} \\
1.89 \times 10^{-3} \\
1.47 \times 10^{-3} \\
1.23 \times 10^{-3} \\
8.32 \times 10^{-4} \\
5.93 \times 10^{-4} \\
5.41 \times 10^{-4} \\
5.41 \times 10^{-4} \\
5.41 \times 10^{-4} \\
4.38 \times 10^{-4} \\
3.38 \times 10^{-4} \\
8.36 \times 10^{-5}\end{array}$ & $\begin{array}{l}\text { Ni-63 } \\
\text { Co-60 } \\
\text { H-3 } \\
\text { Fe-55 } \\
\text { Cs-137 } \\
\text { Ba-137m } \\
\text { Sr-90 } \\
\text { Y-90 } \\
\text { Ni-59 } \\
\text { Pm-147 } \\
\text { U-238 } \\
\text { Pa-234m } \\
\text { Th-234 } \\
\text { Pu-238 } \\
\text { Pu-241 } \\
\text { Eu-154 } \\
\text { Nb-94 } \\
\text { Cs-134 } \\
\text { Sm-151 } \\
\text { Mn-54 } \\
\text { Eu-155 } \\
\text { Sb-125 } \\
\text { Te-125m }\end{array}$ & $\begin{array}{l}1.90 \times 10^{+1} \\
1.08 \times 10^{+1} \\
3.08 \times 10^{0} \\
1.41 \times 10^{-0} \\
7.07 \times 10^{-1} \\
6.70 \times 10^{-1} \\
6.66 \times 10^{-1} \\
6.66 \times 10^{-1} \\
1.41 \times 10^{-1} \\
7.70 \times 10^{-2} \\
2.66 \times 10^{-2} \\
2.66 \times 10^{-2} \\
2.66 \times 10^{-2} \\
2.21 \times 10^{-2} \\
1.79 \times 10^{-2} \\
8.60 \times 10^{-3} \\
6.73 \times 10^{-3} \\
6.36 \times 10^{-3} \\
5.98 \times 10^{-3} \\
4.49 \times 10^{-3} \\
4.11 \times 10^{-3} \\
2.99 \times 10^{-3} \\
7.48 \times 10^{-4}\end{array}$ & $\begin{array}{l}\mathrm{H}-3 \\
\mathrm{Ni}-63 \\
\mathrm{Co}-60 \\
\mathrm{Cs}-137 \\
\mathrm{Ba}-137 \mathrm{~m} \\
\mathrm{Sr}-90 \\
\mathrm{Y}-90 \\
\mathrm{Pu}-241 \\
\mathrm{Fe}-55 \\
\mathrm{Pm}-147 \\
\mathrm{Pu}-238 \\
\mathrm{Ni}-59 \\
\mathrm{Eu}-154 \\
\mathrm{Sm}-151\end{array}$ & $\begin{array}{c}2.65 \times 10^{0} \\
4.04 \times 10^{-2} \\
1.83 \times 10^{-2} \\
1.39 \times 10^{-2} \\
1.33 \times 10^{-2} \\
1.30 \times 10^{-2} \\
1.30 \times 10^{-2} \\
2.66 \times 10^{-3} \\
2.30 \times 10^{-3} \\
1.27 \times 10^{-3} \\
5.26 \times 10^{-4} \\
3.05 \times 10^{-4} \\
1.52 \times 10^{-4} \\
1.22 \times 10^{-4}\end{array}$ & $\begin{array}{l}\mathrm{Pu}-241 \\
\mathrm{Pu}-238 \\
\mathrm{Pu}-240 \\
\mathrm{Pu}-239 \\
\mathrm{U}-238 \\
\mathrm{~Pa}-234 \mathrm{~m} \\
\mathrm{Th}-234 \\
\mathrm{Cm}-244 \\
\mathrm{Am}-241 \\
\mathrm{Th}-232\end{array}$ & $\begin{array}{l}6.45 \times 10^{-4} \\
9.25 \times 10^{-5} \\
3.47 \times 10^{-5} \\
9.95 \times 10^{-6} \\
2.62 \times 10^{-6} \\
2.62 \times 10^{-6} \\
2.62 \times 10^{-6} \\
1.90 \times 10^{-7} \\
1.82 \times 10^{-7} \\
2.13 \times 10^{-8}\end{array}$ \\
\hline
\end{tabular}


TABLE VI. Similarities of Radiological Profiles Between Small and Large DOE Sites

\begin{tabular}{|c|l|l|l|l|l|}
\hline State & $\begin{array}{c}\text { Small DOE } \\
\text { Site }\end{array}$ & $\begin{array}{c}\text { Large DOE } \\
\text { Site }\end{array}$ & State & $\begin{array}{c}\text { Small DOE } \\
\text { Site }^{\mathrm{a}}\end{array}$ & $\begin{array}{c}\text { Large DOE } \\
\text { Site }\end{array}$ \\
\hline IL & ANL-E & ORR (alpha) & CT & KAPL-W & INEL \\
IA & Ames & FEMP & NY & IKAPL-K, & INEL \\
CA & ETEC & ORNL & NY & KAPL-S & INEL \\
CO & GJPO & FEMP & MO & KCP & INEL \\
NM & ITRI & LANL (alpha) & CA & Mare Is & INEL \\
CA & LBL & LLNL & NJ & Middlesex & FEMP \\
OH & Mound & LLNL & VA & Norfolk & INEL \\
NM & SNL-NM (WM) & SRS & HI & Pearl & INEL \\
NM & SNL-NM (ER) & FEMP & FL & Pinellas & LLNL \\
NY & WVDP & HANF & ME & Ports Nav & INEL \\
NY & BNL & ORNL (alpha) & NJ & PPPL & LLNL \\
PA & Bettis & HANF & WA & Puget So & INEL \\
NY & Colonie & FEMP & TX & Pantex & LANL (alpha) \\
SC & Charleston & INEL & OH & RMI & FEMP \\
CA & LEHR & ORNL (alpha) & MO & WSSR & FEMP \\
\hline
\end{tabular}

a Abbreviations: $\mathrm{ANL}=$ Argonne National Laboratory East, Bettis = Bettis Atomic Power Laboratory, BNL $=$ Brookhaven National Laboratory, Charleston $=$ Charleston Naval Shipyard, ETEC = Energy Technology Engineering Center, GJPO $=$ Grand Junction Projects Office, ITRI = Inhalation Toxicology Research Institute, KAPL-K = Knolls Atomic Power Laboratory (Kesselring),

KAPL-S = Knolls Atomic Power Laboratory (Schenectady), KAPL-W = Knolls Atomic Power Laboratory (Windsor), KCP $=$ Kansas City Plant, LBL $=$ Lawrence Berkeley National Laboratory, LEHR = Laboratory for Energy-Related Health Research, Mare Is = Mare Island Naval Shipyard, Middlesex = Middlesex Sampling Plant, Norfolk = Norfolk Naval Shipyard, Pearl = Pearl Harbor Naval Shipyard, Ports Nav = Portsmouth Naval Shipyard, PPPL = Princeton Plasma Physics Laboratory, Puget So $=$ Puget Sound Naval Shipyard, RMI $=$ Reactive Metals, Inc., SNL-NM = Sandia National Laboratories-New Mexico, WSSR = Weldon Spring Remedial Action Project, and WVDP = West Valley Demonstration Project. 
Fig. I. Representative Radionuclide Composition as a Function of Time for a Typical DOE Waste Stream Containing Plutonium 


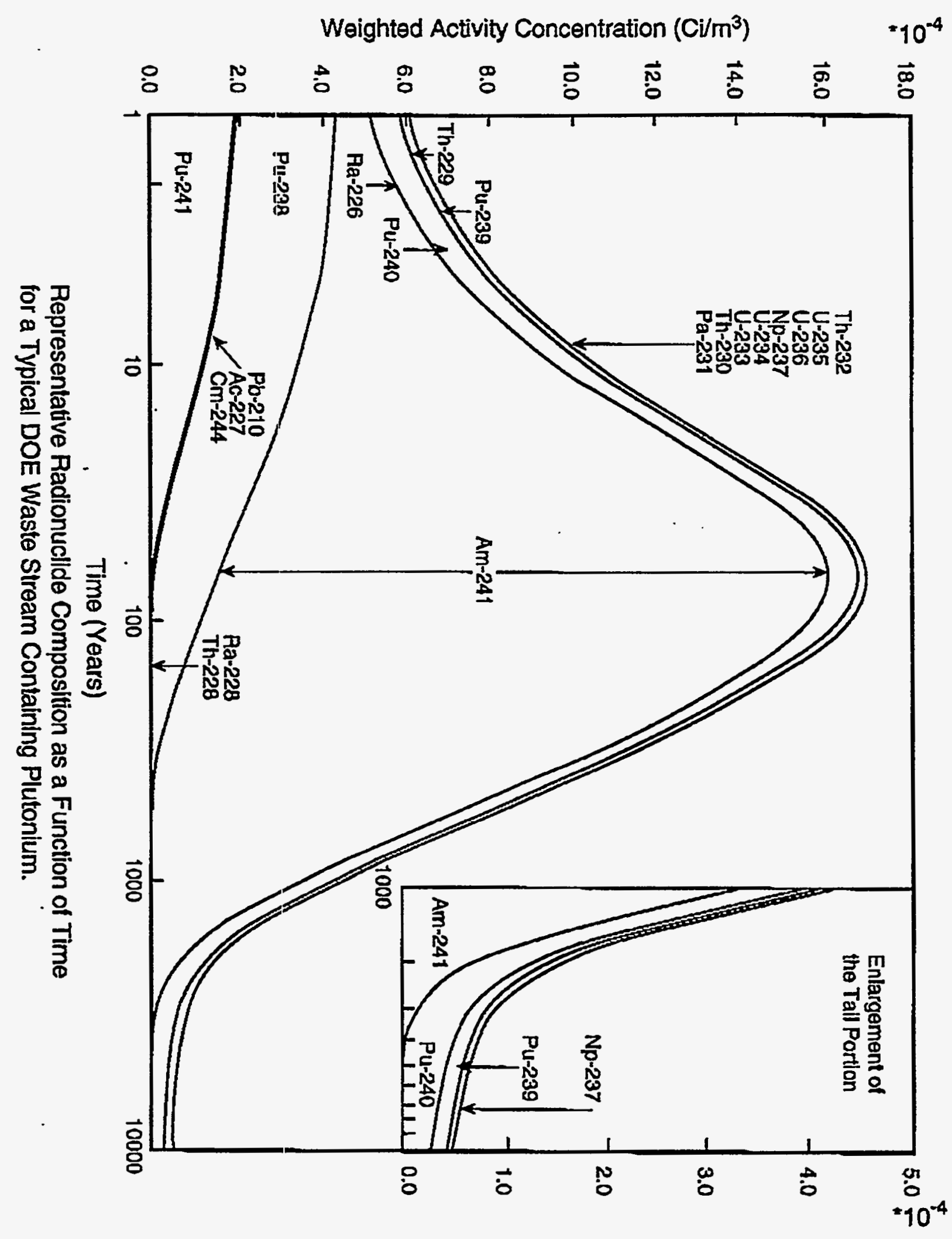

